\title{
Investigation of the Problem Solving and Excellence Levels of the Secondary School Students Who Do Sports and Does Not
}

\author{
Israfil Yasin ${ }^{1}$ \\ Metin $\operatorname{Tan}^{2}$ \\ Filiz Fatma Colakoglu ${ }^{3}$ (D) \\ Muhammed Sahin ${ }^{4}$ (D) \\ ${ }_{1,2,4,3}$ Faculty of Sport Sciences, Gazi University, Ankara, Turkey. \\ Email: israfil_58@hotmail.com \\ Email:metintan58@hotmail.con \\ Email:fcolakoglu@gmail.com \\ Email:mehmetsahino6@windorwslive.com
}

\begin{abstract}
In this study, it was aimed to compare the problem solving and perfectionism levels of the students who do sports and do not sports in terms of various variables, and to determine the correlation between problem solving and their perfectionism. In the province of Among the competitions between secondary schools in the 2018-2019 academic year, Milas district of Muğla province, 171 sports students between the ages of 13-15, whose sports age is at least 2 years, were randomly selected among the sports students. SPSS 22.0 statistics program was used in the analysis of the data. After the descriptive analyzes were made on the data, as the results of the Kolmogorov-Simirnov normality test performed by comparing the scores of the participants were not normal, the difference between the groups was examined by applying the Mann-Whitney test, which is one of the non-parametric tests. The "Mann-Whitney U" test was used to determine the differences between the groups. Statistical analyzes were tested at $95 \%$ confidence level, $\mathrm{p}<0.05$ values were considered statistically significant. Under the "spearman's rho" test for the correlation between perfectionism and problem-solving scale. As a result, although the perfectionism and problem solving levels of the students who do and do not do sports have a meaningful result, the effect of doing sports varies according to gender; We can say that there is a positive correlation in the sub-dimensions of perfectionism and problem solving skills.
\end{abstract}

Keywords: Sport, Perfectionism, Problem solving, Problem solving, Sport and perfectionism, Sport and problem solving, Psychological applications of sport

Citation | Israfil Yasin; Metin Tan; Filiz Fatma Colakoglu; Muhammed Sahin (2020). Investigation of the Problem Solving and Excellence Levels of the Secondary School Students Who Do Sports and Does Not. Asian Journal of Education and Training, 6(3): 499504

\section{History:}

Received: 14 May 2020

Revised: 19 June 2020

Accepted: 21 July 2020

Published: 12 August 2020

Licensed: This work is licensed under a Creative Commons

Attribution 3.0 License $(\mathrm{ccc}) \mathbf{E}$.

Publisher: Asian Online Journal Publishing Group
Acknowledgement: All authors contributed to the conception and design of the study.

Funding: This study received no specific financial support

Competing Interests: The authors declare that they have no conflict of interests.

Transparency: The authors confirm that the manuscript is an honest, accurate, and transparent account of the study was reported; that no vital features of the study have been omitted; and that any discrepancies from the study as planned have been explained.

Ethical: This study follows all ethical practices during writing.

\section{Contents}

1. Introduction

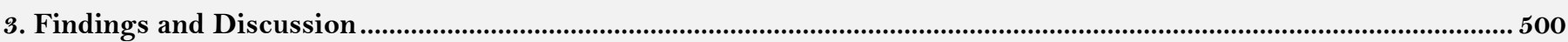

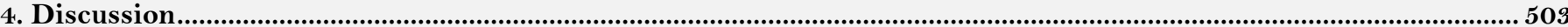

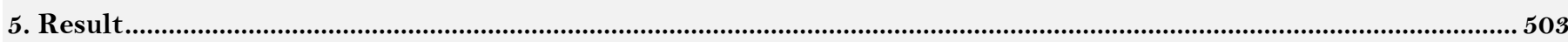

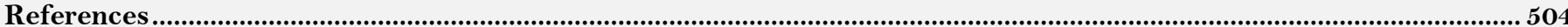




\section{Contribution of this paper to the literature}

This study contributes to the existing literature by comparing the problem solving and perfectionism levels of middle school students who do sports and don't do sports in terms of various variables and analyzing the correlation between problem solving levels and perfectionism levels.

\section{Introduction}

When the history of sports is examined, it is seen that it is imperative that people have a solid body to survive, develop their mobility skills, act to provide the necessary food, drink, make shelter and fight against their enemies. Although sports first appeared as providing nutrition, protection and safety, it developed and changed depending on the environment and the needs of time (Alpman, 1972; Güven, 1999; Pura, 1938). The gains gained during the struggle for survival in nature, which are important for the development of movement, have been disrupted as a result of industrialization and modern cities. To prevent or slow down organic, psychological and physical disorders caused by immobile life as a result of technological developments, sports has been an imperative to maintain physical fitness and health for many years (Kurt, Atayman, \& Congress, 1997; Zorba, 2014). In addition to the characteristics determined by heredity in the physical structure of the life of the human being, its effect is inevitable. Movement is the basic tool in the stage of researching, discovering and learning the world around the individual. Various sports education, learning, training and training that support multi-faceted development should comply with the characteristics of the individual's biological, psychological and social advancement and develop these qualities (Camlıyer \& Camlıyer, 2001; Günay, Cicioğlu, Sıktar, \& Sıktar, 2018).

In addition to being physically strong, sports adds spiritual, mental, emotional and social resilience (Muallimoğlu, 1998). One of the effects of sports on people is perfectionism. It is known that athletes who are at the top level in their branches are mostly perfectionists, and with these features, athletes set high goals that want to struggle hard to reach (Anshel \& Mansouri, 2005; Ashby \& Rice, 2002; Cepikkurt, 2018).

One of the many effects of sport on the human body is its problem solving ability. Problem solving is defined as the cognitive, affective and behavioral remedies that an individual creates and develops to effectively overcome these difficulties in the event of encountering a number of problems (D'Zurilla \& Nezu, 2010). In addition to its genetic features, problem solving skills can be improved by producing solutions to the problems that people face in daily life. Students learn better when they participate in activities prepared in learning environments and solve the problems posed (Dale \& Ballotti, 1997).

In this study, it was aimed to compare the problem solving and perfectionism levels of the students who do sports and not do sports in terms of various variables, and to determine the correlation between problem solving and their perfectionism.

\section{Material Method}

General screening model was used to determine the perfectionism and problem solving levels of middle school students participating in the competition in school sports. Karasar (2018) defines the general screening model as a screening model to apply the whole universe or a group, sample or sample to be taken from the universe in order to understand and make a general judgment.

The framework of the study consisted of 853 students who participated in the inter-secondary competitions organized by the Provincial Directorate of Youth and Sports of Muğla province Milas district between the ages of 13-15 in the academic year 2018-2019. The sample of 171 sports students between the ages of 13-15, whose sports age is at least 2 years, participating in competitions between secondary schools, in Muğla province, Muğla, 169 sedentary students selected randomly from the schools of sports students, a total of 340 volunteer students. SPSS 22.0 statistics program was used in the analysis of the data. After the descriptive analyzes were made on the data, as the results of the Kolmogorov-Simirnov normality test performed by comparing the scores of the participants were not normal, the difference between the groups was examined by applying the Mann-Whitney test, which is one of the non-parametric tests. The "Mann-Whitney U" test was used to determine the differences between the groups. Statistical analyzes were tested at 95\% confidence level, $\mathrm{p}<0.05$ values were considered statistically significant. Under the "spearman's rho" test for the correlation between perfectionism and problem-solving scale.

In the research, Frost Multidimensional Perfectionism Scale was developed by Frost, Marten, Lahart, and Rosenblate (1990); Kağan (2011) which was developed by Frost et al. (1990); Kağan (2011) to measure the perfectionism of students who participated in school sports competitions, while the Perception Scale for Problem Solving Skills developed by Ekici and Balım (2013) was used to determine the level of problem solving.

Excellent consistency test reliability was performed by the inter-item internal consistency method and it was found that the alpha value ranged from 0.63 to 0.87 for general and subtests. Cronbach Alpha reliability coefficient was found to be 0.83 halving reliability coefficient 0.80 (Kağan, 2011). In the reliability studies carried out within the scope of this study, it was found that the multi-dimensional perfectionism scale was performed with the internal consistency values method and the alpha value varied between 0.875 and 0.882 for general and subtests. Cronbach Alpha reliability coefficient was found 0.882.The problem-solving scale consists of two sub-dimensions, and each item gives a Likert type measurement between 1 'strongly disagree' and 5 'fully agree'. It was determined that the variance explained by the first factor of the scale was 30,239\% and the second variance was $10,424 \%$. In addition, the cronbach alpha value of the scale was calculated as 88 (Ekici \& Balım, 2013). In the reliability studies conducted within the scope of this study, the variance explained by the first factor of the problem solving scale was determined to be $32,282 \%$ and the second variance was $12,713 \%$, and the cronbach alpha value of the scale was calculated as 88 .

\section{Findings and Discussion}

In Table 1 , the students participating in the study consist of $190(55.9 \%)$ female students and $150(44.1 \%)$ male students. The study was attended by $77(22.6 \%)$ grade 6 students, $166(48.8 \%)$ grade 7 students, and $97(28.5 \%)$ 
grade 8 students. A total of 340 students, 169 (49.7\%) doing sports and 171 (50.3\%) not doing sports, participated in the study.

Table-1. Distribution of subjects according to variables.

\begin{tabular}{l|c|c}
\hline Gender & $\mathbf{n}$ & $\mathbf{\%}$ \\
\hline Female & 190 & 55,9 \\
\hline Male & 150 & 44.1 \\
\hline Total & 340 & 100,0 \\
\hline Grade & $\mathbf{n}$ & $\mathbf{\%}$ \\
\hline 6. Grade & 77 & 22,6 \\
\hline 7. Grade & 166 & 48,8 \\
\hline 8. Grade & 97 & 28,5 \\
\hline Total & 340 & 100,0 \\
\hline Do they do sports regularly? & $\mathbf{n}$ & $\mathbf{\%}$ \\
\hline No & 169 & 49,7 \\
\hline Yes & 171 & 50,3 \\
\hline Total & 340 & 100,0 \\
\hline
\end{tabular}

Table-2. Differences regarding perfectionism and problem solving sub-dimensions of female students according to variables of doing / not doing sports.

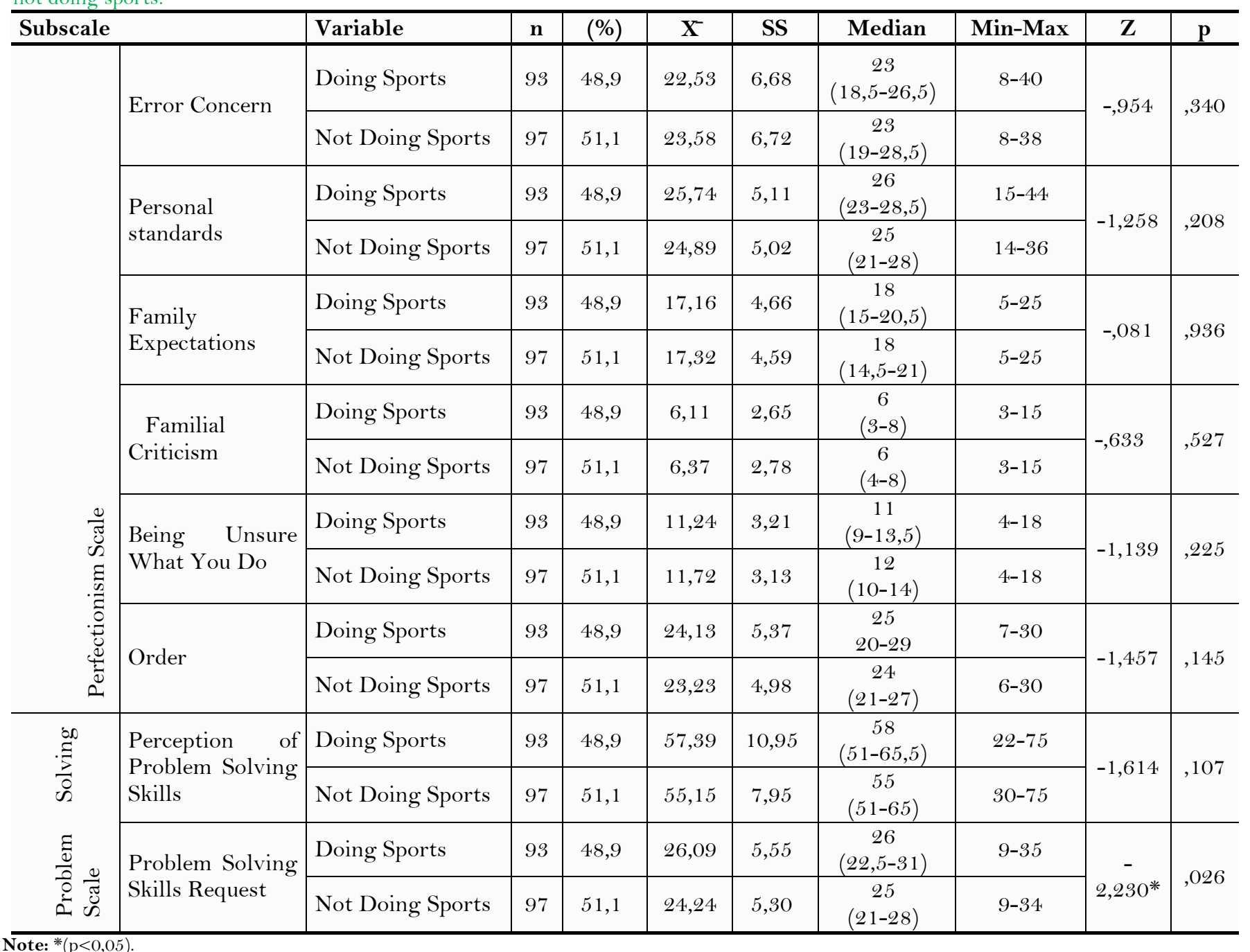

In Table 2 there was no significant difference in the sub-dimensions of perfectionism scale among female students who did / did not do sports ( $\mathrm{p}>0.05)$. Worry about making mistakes (23.58>22.53), familial expectations (17.32>17.16), criticism from the family $(6.37>6.11)$, not being sure $(11.72>11.24)$, It is seen that the average of female students who do not do sports in their subscales is higher than those who do sports. It was found that the mean of female students who do sports $(24.13>23.23)$ and personal standards $(25.74>24.89)$ are higher than the ones who do not do sports. There was no significant difference in the perception of problem solving skills, which was the sub-dimension of the problem solving scale ( $p>0.05)$, but it was found that the average was high in favor of those doing sports $(57,39>55,15)$. There was a significant difference in favor of female students doing sports in requesting problem solving skills $(\mathrm{p}<0.05)$.

In Table 3, a significant difference was found among the male students who did / did not do sports in their averages of perfectionism sub-dimensions or not being sure of making mistakes $(\mathrm{p}<0.05)$. Personal standards (25.59>25.30), familial expectations $(16.93>16.74)$, criticism from the family $(7.18>6.34)$ and order $(23.16>23.07)$ the average of male students is higher than those who do sports. There was a significant difference in the problem solving skills sub-dimension, which is the problem solving scale sub-dimension $(\mathrm{p}<0.05)$. On the sub-dimension of the problem solving skills perception, there was no significant difference $(\mathrm{p}>0.05)$, but statistically, sports averages were found to be higher than those who did not do sports $(53.93>52.43)$. 
Table-3. Differences regarding perfectionism and problem solving sub-dimensions of male students according to variables of doing / not doing sports.

\begin{tabular}{|c|c|c|c|c|c|c|c|c|c|c|}
\hline \multicolumn{2}{|c|}{ Subscale } & Variable & $\mathbf{N}$ & $(\%)$ & $X^{-}$ & SS & Median & $\begin{array}{l}\text { Min- } \\
\text { Max }\end{array}$ & $\mathbf{Z}$ & $\mathbf{p}$ \\
\hline & \multirow{2}{*}{ Error Concern } & Doing Sports & 78 & 52 & 20,96 & 7,67 & $\begin{array}{c}20 \\
(16-20,25) \\
\end{array}$ & $8-40$ & \multirow{2}{*}{$-2,439^{*}$} & \multirow{2}{*}{,015 } \\
\hline & & Not Doing Sports & 72 & 48 & 23,26 & 5,99 & $\begin{array}{c}24 \\
(20-27) \\
\end{array}$ & $8-34$ & & \\
\hline & \multirow{2}{*}{$\begin{array}{l}\text { Personal } \\
\text { Standards }\end{array}$} & Doing Sports & 78 & 52 & 25,30 & 5,92 & $\begin{array}{c}25 \\
(21,75-29,25) \\
\end{array}$ & $8-40$ & \multirow{2}{*}{,- 743} & \multirow{2}{*}{,458 } \\
\hline & & Not Doing Sports & 72 & 48 & 25,59 & 5,58 & $\begin{array}{c}26 \\
(23-29) \\
\end{array}$ & $8-38$ & & \\
\hline & \multirow{2}{*}{$\begin{array}{l}\text { Family } \\
\text { Expectations }\end{array}$} & Doing Sports & 78 & 52 & 16,74 & 4,71 & $\begin{array}{c}17 \\
(14-20) \\
\end{array}$ & $5-25$ & \multirow{2}{*}{,- 294} & \multirow{2}{*}{,769 } \\
\hline & & Not Doing Sports & 72 & 48 & 16,93 & 4,20 & $\begin{array}{c}17 \\
(15-20) \\
\end{array}$ & $5-25$ & & \\
\hline & \multirow{2}{*}{$\begin{array}{l}\text { Familial } \\
\text { Criticism }\end{array}$} & Doing Sports & 78 & 52 & 6,34 & 2,70 & $\begin{array}{c}6 \\
(4-8)\end{array}$ & $3-14$ & \multirow{2}{*}{$-1,526$} & \multirow{2}{*}{, 127} \\
\hline & & Not Doing Sports & 72 & 48 & 7,18 & 3,19 & $\begin{array}{c}7 \\
(4-9,75) \\
\end{array}$ & $3-15$ & & \\
\hline \multirow{4}{*}{ 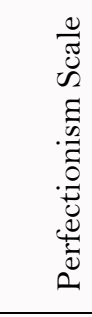 } & \multirow{2}{*}{$\begin{array}{l}\text { Being Unsure } \\
\text { What You Do }\end{array}$} & Doing Sports & 78 & 52 & 10,93 & 3,41 & $\begin{array}{c}10 \\
(8,75-13) \\
\end{array}$ & $4-20$ & \multirow{2}{*}{$-2,597^{*}$} & \multirow{2}{*}{,009 } \\
\hline & & Not Doing Sports & 72 & 48 & 12,09 & 3,01 & $\begin{array}{c}12 \\
(11-14) \\
\end{array}$ & $4-18$ & & \\
\hline & \multirow{2}{*}{ Order } & Doing Sports & 78 & 52 & 23,07 & 5,62 & $\begin{array}{c}24 \\
(21-28) \\
\end{array}$ & $6-30$ & \multirow{2}{*}{,- 023} & \multirow{2}{*}{, 982} \\
\hline & & Not Doing Sports & 72 & 48 & 23,16 & 5,36 & $\begin{array}{c}24 \\
(19,25-27) \\
\end{array}$ & $6-30$ & & \\
\hline \multirow{2}{*}{ 离 } & \multirow{2}{*}{$\begin{array}{l}\text { Perception of } \\
\text { Problem } \\
\text { Solving Skills }\end{array}$} & Doing Sports & 78 & 52 & 53,93 & 13,22 & $\begin{array}{c}56 \\
(48,75-62,25)\end{array}$ & $15-75$ & \multirow{2}{*}{$-1,743$} & \multirow{2}{*}{,081 } \\
\hline & & Not Doing Sports & 72 & 48 & 52,43 & 9,83 & $\begin{array}{c}52 \\
(47-59)\end{array}$ & $22-75$ & & \\
\hline \multirow{2}{*}{$\begin{array}{l}\frac{\Xi}{0} \\
\stackrel{0}{0} \\
0 \\
0 \\
0\end{array}$} & \multirow{2}{*}{$\begin{array}{l}\text { Problem } \\
\text { Solving Skills } \\
\text { Request }\end{array}$} & Doing Sports & 78 & 52 & 24,93 & 6,49 & $\begin{array}{c}26 \\
(21-30) \\
\end{array}$ & $7-35$ & \multirow{2}{*}{$-2,193^{*}$} & \multirow{2}{*}{,028 } \\
\hline & & Not Doing Sports & 72 & 48 & 23,12 & 5,57 & $\begin{array}{c}22,50 \\
(19,25-27)\end{array}$ & $8-35$ & & \\
\hline
\end{tabular}

Table-4.Differences in excellence and problem solving subscales of male and female students doing sports.

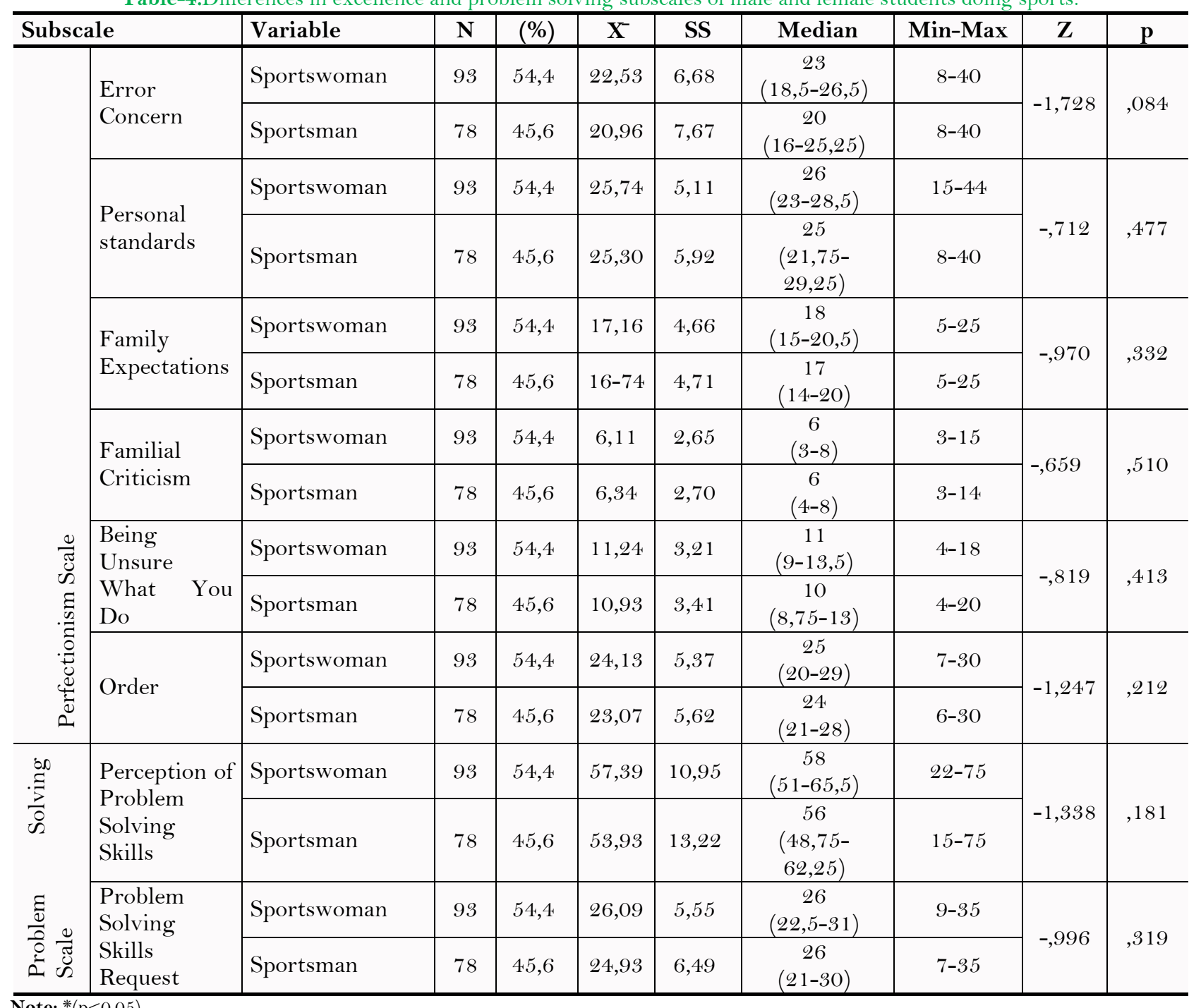


Table 4 shows the average perfectionism scale between men and women doing sports. Worrying about making mistakes (22.53>20.96), personal standards (25.74>25.30), familial expectations (17.16>16.74), being unsure $(11.24>10.93)$, The mean $(24.13>23.07)$ sub-dimension means that female students are higher than male students. There was no significant difference in the sub-dimensions of the problem-solving scale $(\mathrm{p}>0.05)$. it is determined that the problem solving skills request (57.39>53.93) and the problem solving skills perception (26.09>24.93) are high.

Table-5.Perfectionism scale sub-dimensions and problem-solving skills sub-dimensions correlation analysis results.

\begin{tabular}{|c|c|c|c|c|c|c|c|c|}
\hline \multirow[t]{2}{*}{$\begin{array}{c}\text { Sub } \\
\text { dimensions }\end{array}$} & \multicolumn{2}{|c|}{$\begin{array}{c}\text { Problem Solving Skills } \\
\text { Scale }\end{array}$} & \multicolumn{6}{|c|}{ Perfectionism Scale } \\
\hline & PSS & PSSR & EC & PS & FE & FC & BU & $\mathbf{O}$ \\
\hline PSS & 1,000 & $0,427 * *$ & $-0,190^{* *}$ & $0,212^{* *}$ & $0,228 * *$ & $-0,296 * *$ & $-0,115^{*}$ & $0,464 * *$ \\
\hline PSSR & & 1,000 & $-0,446^{* * *}$ & $-0,028$ & 0,014 & $-0,474 * *$ & $-0,383^{*} *$ & $0,316^{* * *}$ \\
\hline $\mathrm{EC}$ & & & 1,000 & $0,453^{* *}$ & $0,319^{* *}$ & $0,495^{* *}$ & $0,663^{* *}$ & $-0,063$ \\
\hline PS & & & & 1,000 & $0,598^{* *}$ & $0,198 * *$ & $0,350^{* * *}$ & $0,344^{*} * *$ \\
\hline $\mathrm{FE}$ & & & & & 1,000 & 0,084 & $0,276^{* *}$ & 0,399** \\
\hline $\mathrm{FC}$ & & & & & & 1,000 & $0,441^{*} *$ & $-0,286^{* * *}$ \\
\hline $\mathrm{BU}$ & & & & & & & 1,000 & 0,048 \\
\hline $\mathrm{O}$ & & & & & & & & 1,000 \\
\hline
\end{tabular}

Problem Solving Scale sub-dimensions: (PSS: Problem Solving Skills, PSSR: Problem Solving Skill Request,) Perfectionism Scale sub-dimensions: (EC: Error Concern, PS: Personal Standards, FE: Familial Expectations, FC: Familial Criticism, BU: Being Unsure What You Do, O: Order).

It was determined that problem solving skills and problem solving skills desire, personal standards, familial expectations, and anxiety of making a positive relationship in the sub-dimensions of the order, making a negative relationship in the criticism dimension and being unsure that the sub-dimension was weakly negative. There was a positive relationship in the sub-dimension of order and problem solving skills, and a weak positive relationship in the sub-dimension of family expectations; there is a negative relationship in the sub-dimensions of anxiety about making mistakes, familial criticism, being unsure of what it is doing; It was determined that there was a weak negative relationship in the personal standards dimension.

\section{Discussion}

Many researchers suggest that perfectionism occurs as a result of social learning gained consciously or unconsciously during childhood. According to these researchers, perfectionism is not only transferred genetically to the individual. The children of the perfectionist family show excellenceist behaviors due to their families' expectations (Adderhold-Alliot, 1987; Cepikkurt, 2018). Another feature affected by other environmental factors is problem solving. The development of problem-solving abilities contributes to achieving their goals in a conscious and planned manner, to act with a result-oriented approach, to combat confrontation, stress and life difficulties. The problem solving ability developed contributes to the reduction of mental health problems such as anxiety and depression by reducing the negative effects of the problems (D'Zurilla \& Nezu, 2010; Norris, 2003). Students who want to meet the expectations of their families and teachers, the equivalent. Although this perspective, which is far from the reality of everyday life, increases the academic achievement of the students to a certain extent, it prevents them from being a sharing, helpful and responsible individual in the social environment they live in SchonertReichl and Hymel (2007) accepted.

In the study conducted by Cepikkurt (2012) with 246 university students playing handball with a multidimensional perfectionism scale specific to sports, the perfectionism scores of handball players were significantly different in terms of gender $(t=-2,303 ; \mathrm{p}<0.05)$. They found that they scored higher according to their scores, but there was no significant difference between personal standards and family pressure subscale scores. In their study using the perfectionism scale with 10elit athletes in Anshel and Mansouri (2005) they obtained a statistically significant difference in terms of genders. The results indicated that women scored higher in terms of familial expectations and criticism than men, while men scored higher than women in order and organization.

In the study of Ozen (2019) with 208 elite taekwondo players, he found that there was a difference between male and female taekwondo in the sub-dimensions of perfectionism scale according to gender variable, according to the results of sub-dimensions of perfectionism scale, perceived family pressure, personal standards, showing power, external regulation and motivation. ( $\mathrm{p}<0.05)$.In Ozdemir (2019) 156 women $(\overline{\mathrm{x}}$ age $=19.52 \pm 2.63)$, 146 men $(\overline{\mathrm{x}}$ age $=19.92 \pm 2.78)$ made a total of $302\left(\mathrm{x}^{-}\right.$age $\left.=19.71 \pm 2.70\right)$ team athletes. In the study, as a result of examining sub-dimensions of perfectionism scale according to gender variable, they did not find a significant difference between male athletes and female athletes in personal standards and perceived family pressure, but they found a significant difference in sub-dimension.

In the study conducted by Pulur, Karabulut, and Koç (2012) with high-level athlete university students, they obtained a significant difference in their problem-solving skills in terms of gender. They found that there was a significant difference $(78.33 \pm 11.32)(92.57 \pm 20.85)$ between the female athletes and the male athletes' problemsolving skills. They stated that there was no difference in the gender dimension of their solving skills. In Ersoy (2019) study conducted with 458 sports secondary school students, they found that there was no significant difference in the problem solving scale sub-dimensions in terms of gender variable ( $p>0.05)$.

\section{Result}

When the female students who do sports / don't do sports are examined according to the sub-dimensions of perfectionism scale, there is no significant difference, but it is found that the average of personal standards and order sub-dimension is high in women who do sports, their anxiety about making mistakes, familial expectations, 
criticism from the family and not being sure that they do not. It was. It was determined that there was no significant difference in the perception of problem solving skills, which is the sub-dimension of the problem solving scale. However, a significant difference was obtained in the request of problem solving skills, which was high in favor of athletes $(\mathrm{p}<0.05)$.

When the male students doing / not doing sports were examined according to the sub-dimensions of perfectionism scale, a significant difference was found in favor of those who did not do sports $(\mathrm{p}<0.05)$; It was found that the average of personal standards, familial expectations, criticism from the family and order subdimensions were high in favor of non-sports people. There was no significant difference in the perception of problem solving skills, which was the sub-dimension of the problem solving scale, but a mean difference was obtained in the request for problem solving skills, whereas the mean was high in favor of athletes $(\mathrm{p}<0.05)$.

There was no significant difference in the sub-dimensions of the perfectionism scale of women / men doing sports $(p>0.05)$, but it was found that the average of female athletes was higher in the anxiety of making mistakes, personal standards, familial expectations, not being sure and doing order. There was no significant difference in the sub-dimensions of the scale ( $\mathrm{p}>0.05)$, but their averages are high in favor of women.

When the correlation results of perfectionism and problem solving scale sub-dimensions are evaluated, there is a positive relationship between problem solving skills and problem solving skills, personal standards, family expectations and order sub-dimensions; It has been determined that there is a positive relationship between problem solving skills and order sub-dimension.

As a result, the effect of doing sports, where the levels of perfectionism and problem solving of the students who do not / do sports differ, varies according to gender; We can say that there is a positive correlation in the subdimensions of perfectionism and problem solving skills.

\section{References}

Adderhold-Alliot, M. (1987). Perfectionism: What's bad about being too good? Minneapolis: Free Spirit Publishing.

Alpman, C. (1972). Physical education and its development throughout the ages in the integrity of education (pp. 7). İstanbul: Millî Education Press.

Anshel, M. H., \& Mansouri, H. (2005). Influences of perfectionism on motor performance, affect and causal attributions in response to critical information feedback. Journal of Sport Behavior, 28(2), 99-124.

Ashby, J. S., \& Rice, K. G. (2002). Perfectionism, dysfunctional attitudes, and self-esteem: A structural equations analysis. Journal of Counseling $\mathcal{E}^{2}$ Development, 80(2), 197-203. Available at: https://doi.org/10.1002/j.1556-6678.2002.tbo0183.x.

Camlıyer, H., \& Camlıyer, H. (2001). Child movement education and play in education integrity (pp. 17). Manisa: Emek Matbaacılık.

Cepikkurt, F. (2012). Investigation of the relationship between perfectionism and anxiety levels of university handball players and their success goals and the way they load on competition results. Ph.D. Thesis, Çukurova University Institute of Health Sciences.

Cepikkurt, F. (2018). Perfectionism and causal loading in sports (pp. 3). Istanbul: Atlas Academic Press Release.

D’Zurilla, T. J., \& Nezu, A. M. (2010). Problem-solving therapy, in Handbook of Cognitive-Behavioral Therapies, Ed:Keith,S. D (3rd ed., Vol. 3, pp. 197-225). New York, U.S.A: The Guilford Press.

Dale, P. M., \& Ballotti, D. (1997). An approach to teaching problem solving in the classroom. College Student Journal, 31 (1), $76-79$.

Ekici, D. İ., \& Balım, A. G. (2013). Perception scale for problem solving skills for secondary school students: validity and reliability study. Yüzüncü Yil University Faculty of Education Journal, 10(1), 67-86.

Ersoy, M. (2019). Investigation of the effects of leadership characteristics of active secondary school students on problem solving skills. Master Thesis, Kütahya Dumlupinar University Institute of Social Sciences.

Frost, R. O., Marten, P., Lahart, C., \& Rosenblate, R. (1990). The dimensions of perfectionism. Cognitive Therapy and Research, 14(5), 449-468. Günay, M., Cicioğlu, İ., Sıktar, E., \& Siktar, E. (2018). Excitement in child-old women and special groups (pp. 133). Ankara: Gazi Bookstore. Güven, O. (1999). Sports culture in Turks (Vol. 172, pp. 1). Ankara: Atatürk Culture Language and History High.

Kağan, M. (2011). Psychometric properties of the Turkish version of Frost multidimensional perfectionism scale. Anatolian Journal of Psychiatry, 12(3), 192-197.

Karasar, N. (2018). Scientific research methods (33rd ed.). Ankara: Nobel Publishing.

Kurt, M., Atayman, V., \& Congress, T. (1997). Show in the Arena: Past and present of modern sports (pp. 82). İstanbul: Issue Publications.

Muallimoğlu, N. (1998). Physical education for children and youth (pp. 7). Istanbul: Avcıol Printing-Publishing.

Norris, J. A. (2003). Looking at classroom management through a social and emotional learning lens. Theory into Practice, 42(4), $313-318$. Available at: https://doi.org/10.1207/s1543042 1 tip4204_8.

Ozdemir, İ. (2019). The role of perfectionism and success targets in determining prosocial and antisocial behaviors of adult athletes engaging in team sports. Master Thesis, Istanbul University Institute of Health Sciences.

Ozen, A. (2019). Investigation of the relationship of multidimensional perfectionism levels of Taelwondo athletes in the $Y$ and $Z$ generation with motivation and success motivation in sport. Master Thesis, Selcuk University Institute of Health Sciences.

Pulur, A., Karabulut, O., \& Koç, H. (2012). A review of the problem-solving skills of high level collegiate athletes from different branches. Spormetre Journal of Physical Education and Sports Sciences, 10(1), 1-6.

Pura, F. (1938). Gymnastics. Istanbul: State Printing House.

Schonert-Reichl, K. A., \& Hymel, S. (2007). Educating the heart as well as the mind social and emotional learning for school and life success. Education Canada, 47(2), 20-25.

Zorba, E. (2014). Lifelong sports (Vol. 3, pp. 16-23). Ankara: Atalay Matbaacılık. 